\title{
The Effect of Firm Size, ROA and Executive Character on Tax Avoidance
}

\author{
$1^{\text {st }}$ Firman Zaro Waruwu \\ Program Studi Akuntansi Manajerial \\ Politeknik Negeri Batam \\ Batam, Kepulauan Riau \\ firmanwaruwu12@gmail.com
}

\author{
$2^{\text {nd }}$ Ely Kartikaningdyah \\ Program Studi Akuntansi Manajerial \\ Politeknik Negeri Batam \\ Batam, Kepulauan Riau \\ ely@polibatam.ac.id
}

\begin{abstract}
Tax avoidance is a practice that impedes state revenues because the country's biggest income comes from taxes. This study aims to examine firm size, Return on asset (ROA) and executive character towards tax avoidance. The object of research was taken from the data of manufacturing companies in the Indonesia Stock Exchange in 2010-2017. The test results showed that firm size had no effect on tax avoidance, while ROA and executive character had a significant negative effect on tax avoidance. These results provide an understanding that the greater the value of ROA and the more executives dare to take risks; the level of tax avoidance by the company will increase. This study has limitations in terms of the number and measurement of variable data, so that the next researcher adds variables that are thought to influence tax avoidance such as political connections, fixed asset intensity and inventory intensity. In addition, adding the amount of data in the form of quarterly financial statements to find out more detailed company characteristics.
\end{abstract}

Keywords - tax avoidance, agency theory, firm size, executive character, return on asset

\section{INTRODUCTION}

Revenue from taxation is the largest contribution to state revenues to date. The state realizes that to carry out development for the sake of people's welfare, it must be balanced with adequate income or income so that the development target can be achieved. One of the revenues is contributed by the people or taxpayers through tax payments to the government, so that the government can process these revenues to finance state expenditures that have an impact on people's welfare. The process of tax revenue is something that can be imposed by the state on taxpayers and is a necessity to be given by taxpayers even though they do not receive direct reciprocal services [31]. In this regard, many taxpayers consider that paying taxes is only a burden that does not have a direct impact on them.

Tax avoidance is one alternative that can be done by taxpayers to reduce or pay taxes to a minimum. According to [15], tax avoidance is done legally which does not violate tax regulations by looking for loopholes or weaknesses in tax regulations. The practice of tax avoidance shows that there are still people who are not yet aware of the concept of the people, by the people and for the people. This can be seen from the receipt of realization of tax revenues that have not been able to reach or exceed the $100 \%$ target and even the last three years of 2015-2017 are still below 90\% [8]. The tax revenue realization deficit can occur by various factors and one of them is indicated as an impact of the existence of tax avoidance practices. This fact then makes researchers interested in finding factors or variables that influence tax avoidance practices, especially corporate taxpayers in Indonesia.

Based on the summary of the amendment to the 2010-2017 state budgets, it was found that the tax revenue target or budget has a very high contribution, namely the average is $79.23 \%$ of the total state revenue budget [9]. The revenue budget does not always run positively $100 \%$ of the average realization of tax revenues which is only $90.53 \%$ from 2010-2017 [9] .These results indicate that in fact there are still tax revenues that can actually be maximized to reach the revenue target.

Factors suspected of influencing corporate tax avoidance are firm size, return on asset (ROA) and executive character. The size of a company can be seen with the size of the company's total assets. The larger total assets indicate that the company has a large size. Large companies will have good management in terms of operations and in terms of their performance in managing their resources, making it possible also that the company can carry out tax management in the form of tax avoidance. Research [7] found that corporate tax avoidance practices were significantly influenced by firm size in a linear / positive direction. The results found by [22], namely tax avoidance practices are influenced by the size of the company with a negative direction, while [28] found that the practice of tax avoidance is not influenced by the size of the company.

Return on asset can be used as a benchmark to indicate the occurrence of tax avoidance. The greater the ROA value of a company shows the company is able to generate profits from the total assets owned more effectively. This allows the company to carry out tax management so as not to pay taxes too high. Research on the effect of ROA on tax avoidance has been carried out by [7] who found that ROA had a significant and positive effect on tax avoidance. Different results were found 
by [22], [1], [3] and [29] namely ROA has a significant negative effect on tax avoidance, even there was a previous study which found that ROA did not significantly influence tax avoidance, namely research by [27].

Another variable used to determine the tax avoidance factor is the executive character. Some previous studies found that executive characters have a negative influence on tax avoidance practices by [4], [12] and [6]. Different results were found by [29] who found that executive character had a positive effect on tax avoidance. The executive character that has a significant effect on tax avoidance shows that executives who are aggressive in taking risks will be more dominant in tax avoidance.

Previous research used more populations of service companies with a sample year range of 3 to 5 years and company financial statement data was taken from the Indonesia Stock Exchange database. This study uses a population of manufacturing companies listed on the Indonesia Stock Exchange. The sample year used was 8 years, from 2010-2017 and financial report data was obtained from the official Wharton Research Data Services (WRDS) website in the Osiris database that had the qualifications to present factual data.

The formulation of the problem to be answered through this research is whether firm size, ROA and executive character have a significant negative effect on tax avoidance, so the purpose of this study is to examine the effect of firm size, ROA, and executive character on tax avoidance.

The theoretical benefits of this research are expected to provide understanding and knowledge regarding whether or not the influence of firm size, ROA and executive character on tax avoidance is affected or not. Practical benefits are expected that this research can provide an alternative for tax parties in assessing the variables that most influence the practice of tax avoidance by companies, so as to provide an idea to the government in arranging regulations on variables that effect tax avoidance practices. This study limits the companies that will be examined as populations, namely only using manufacturing companies listed on the Indonesia Stock Exchange from 20102017. The chosen year limit is because this year the effective $25 \%$ rate has been applied which previously $28 \%$ for corporate tax was.

\section{THEORY AND LITERATURE REVIEW}

\section{Agency theory}

[16] Suggest that the owner (principal) provides trust in the form of an agreement to the manager (agent) of the company to carry out the operations of a company. This relationship indicates that the agent as the party that is given the trust will be bound by the principal in carrying out the authority he has received. J[16] believe that if the objective of the principal and agent is to maximize utility (relative satisfaction to be achieved), the agent will not always act in the interest of the principal. Agents will look for ways to maximize income from the company's operations in order to be able to finance activities in operations, so that there are several differences in decisions between what is desired by the principal and the agent.
Management tends to report a decrease in profit or income when having bonus plans with binding upper and lower limits. If not bound by the upper and lower limits of bonus planning, management tends to report an increase in profits [14]. That is, when the company has a binding bonus plan (already arranged), the company is obliged to give bonuses on a routine basis when the company profits are high or are between the lower and upper limits. Such obligations will be a burden on the company in paying the bonus, so the company will tend to do discretionary accruals to reduce profits. This behavior illustrates that management (agent) has the ability to report company profits in accordance with company planning, consequently with little reporting of profits will reduce the tax to be paid by the company. This is happen because management has the opportunity to carry out tax management.

The tax collection system implemented in Indonesia gives confidence to taxpayers to calculate and report on the amount of tax that must be paid which is called a self-assessment system. According to [2], taxpayers have two choices of strategies in reporting their taxable income, namely choosing to report income actually or reporting part / less of actual income. This option provides an opportunity for taxpayers to make less tax calculations than they really are. These various statements will then be used as the basis for finding empirically variables or factors that influence taxpayers in practicing tax avoidance.

\section{Tax Avoidance}

Legitimate taxpayer activities to reduce tax costs owed by utilizing or looking for loopholes and weaknesses in tax regulations are called tax avoidance [15]. This statement allows each taxpayer not to pay taxes maximally because every rule that has been given has its own shortcomings or weaknesses. Tax evasion activities that are usually carried out are maximizing costs to reduce income or seek income received not as tax objects [26].

Another tax avoidance technique that is usually done by exploiting tax weaknesses is to delay income (receipt) when in that period the company has a very high income, so that it can be delegated to the next period.

\section{Firm size}

The majority of firm size can be seen from how much a company has total assets. Companies that have relatively large total assets indicate that the company has a large size both physically and operationally. Companies with large sizes will be balanced with large operational activities, so that the company's income or profits will also be large. Large companies tend to strive to avoid the increase in profits that are too drastic so as not to cause an increase in the income tax that is too large [14]. The technique used by company managers in minimizing profits is done by choosing an accounting method so that income can now be recognized in the next period [35].

\section{Return On asset}

The company's ability to generate profits using assets owned by the company can be known by the value of the ROA ratio. Agency theory allows agents to maximize profits as large 
as [7]. The agent realizes that with this increase in profits, it will be followed by an increase in the income tax that must be paid by the company. This situation will make the agent or management of the company to manage taxes so that the company does not pay large amounts of tax according to agency theory.

\section{Executive Character}

The executive is a very influential party in a company because it is the decision maker that the company will run. The executive character is very influential in risk taking and risk aversion. [24] Found that executive risk takers are more optimistic and too confident in future decision-making and dare to make more risky financing. This character will make the company carry out financing activities such as debt that creates interest expense, thereby reducing profits which ultimately make the company's income tax decrease.

\section{DEVELOPMENT OF HYPOTHESIS}

\section{The Effect of Firm size on Tax Avoidance}

Large companies generally have operational activities on a larger scale. Large companies are also able to have experts in managing their own resources for a long period of time compared to small companies that are still not optimal in managing the resources they have. Good management allows large companies to be able to make arrangements in terms of production and sales. When income increases drastically, large companies are able to defer income to the next period or in other words, the income does not want to be recognized in this period but is recognized for the next period. The deferred income has an impact on earnings that look smaller, resulting in fewer tax payments. The technique by company managers in minimizing profits is done by selecting accounting methods so that current income can be recognized in the next period [35]. The company dares to do this because it has adequate resources or assets, so that even though the deferral of income results in no increase in receivables or cash, it can still be controlled with available assets.

Research [7] found that there was a significant positive relationship between firm size and tax avoidance. Different results were found by [22] that firm size negatively affected tax avoidance, while [28] found that firm size did not affect tax avoidance. The results of previous studies that found the size of the company influences tax avoidance, explaining that largescale companies will have large resources to use with certain objectives, including in reducing the company's income tax. Based on the description above, the formulation of the first research hypothesis is as follows:

H1: Firm size has a significant negative effect on tax avoidance.

\section{The Effect of Return on Asset on Tax Avoidance}

Companies are said to be efficient in using assets if they have a high return on asset ratio. A high ROA value indicates that the company's assets are used maximally by the company to generate income, but the company is also aware that large revenues will result in high profits followed by large tax payments. This makes the company tend to invest its assets in receipt of non-tax revenue. One alternative that can be done by the company is to open a new line or invest in another company more than $25 \%$ so that dividend receipts are not taxed [21]. This alternative makes reported profits look bigger, but less paid taxes and management tends to report profit increases when there is no binding bonus planning [14].

[7] Found that ROA had a significant and positive effect on tax avoidance. Different results were found by [22], [1] and [29] that ROA has a significant negative effect on tax avoidance. Another result found that ROA did not significantly influence tax avoidance, namely by [27]. Based on the description above, the formulation of the second research hypothesis is as follows: H2: Return On Asset has a significant negative effect on tax avoidance.

\section{The Effect of Executive Character on Tax Avoidance}

The executive is the party that gives the decision to be run by the company. Each of these decisions will affect the company's activities as a whole. Executives who have a risk taker character will be more courageous in making decisions, especially in making financing originating from debt that can be at risk of causing bankruptcy [23]. This debt financing is used to maximize company utility and will generate interest on debts that must be paid by the company each period. The interest is recognized by taxation as a deduction from income so that profits will be smaller and taxes to be paid will also be small. The character of the risk taker executive can be seen from the higher standard deviation of earnings (earnings before interest, tax, depreciation, and amortization) divided by total assets [25]

Several previous studies found that executive character negatively affected tax avoidance by [4], [12] and [6]. Research by [29] found that executive character had a positive effect on tax avoidance. Research on the character of executives needs to be explored again to find out the effects on corporate tax avoidance. Based on the description above, the formulation of the third research hypothesis is as follows:

H3: Executive character has a significant negative effect on tax avoidance.

Based on the description of the development of the hypotheses that have been explained, the research variables used are described in the research model as follows:

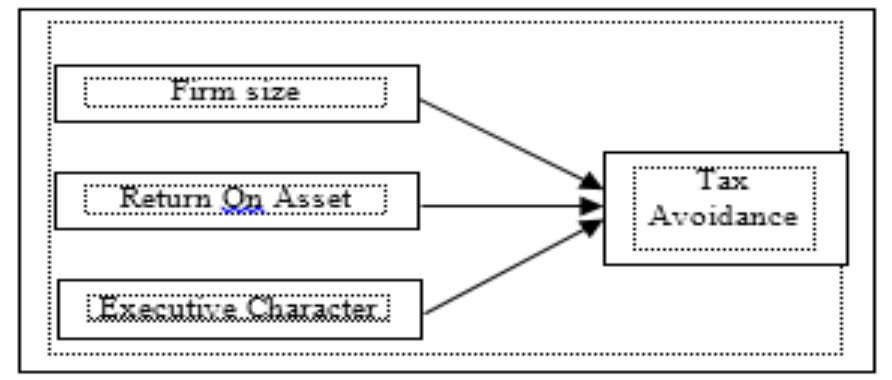

Fig. 1. Research Model 


\section{RESEARCH METHOD}

\section{Population and Sample}

The data used is secondary data that can be accessed through the official Wharton Research Data Services (WRDS) website [35] which is recorded in the Osiris database according to the companies sampled. The population in the study is a manufacturing company listed on the IDX and secondary data [5],[17],[18],[19],[20] The sampling technique used was purposive sampling technique. Criteria for sampling are: 1) Manufacturing sector companies that are listed on the Indonesia Stock Exchange in 2010-2017, because this year the company has applied a $25 \%$ rate effectively which previously was $28 \%$; 2) The company earns income before tax (no loss) in the study year, because the company that loses can compensate in the following year; 3) The company prepares its financial statements in rupiah units because foreign currencies have a fluctuating or uncertain exchange rate with the rupiah; 4) Has an ETR value smaller than 1, because companies that have an ETR value greater than one are companies that experience various fines in that period; 5) Companies meet criteria 1-4 for 8 years in a row.

\section{Definition of Operational Variables and Measurement}

\section{A. Tax Avoidance}

The series of activities carried out for the purpose reducing the income tax by utilizing defects or weaknesses in tax regulations by taxpayers is referred as tax avoidance [15]. Tax avoidance can be known through the value of effective tax rate (ETR) which can be used to describe fixed differences and earnings temporary differences according to commercial accounting and profit according to fiscal [10]. The smaller the ETR value, the company is indicated to have a high tax avoidance practice. This effective tax rate is measured by the total income tax divided by earnings before tax [10] as below:

$$
\text { ETR }=\frac{\text { Income Tax }}{\text { Earnings Before Tax }}
$$

\section{B. Company Size}

The scale of large or small companies which generally can be known through the number of assets owned by the company is referred to as firm size. [13] States that firm size can be measured by using natural logarithms of the company's total assets. These measurements are considered to have a continuing tendency between periods and also have more stability than other proxies. Natural logarithms of total assets can describe the size of a company whose formula is shown as follows [13]:

$$
\text { Firm size }=\text { Ln }(\text { Total Assets })
$$

\section{Return On Asset (ROA)}

[30] States that the company's management ability to maximize the utilization of total assets as a whole in generating profits can be seen through financial ratios, namely return on asset (ROA). The higher the value of ROA, it shows that the management performance in the company is getting better at maximizing the use of assets owned to generate corporate profits. Earnings after tax divided by total company assets is used as a measure of ROA [21] as follows:

$$
R O A=\frac{\text { Earnings After Tax }}{\text { Total Asset }}
$$

\section{Executive Character}

The executive characteristic is the behavior of an executive in making decisions to take risks or choose to avoid these risks. [25] states that the measure in assessing a risk is fluctuations in the company's income. In addition, EBITDA (earnings before interest, taxes, depreciation and amortization) divided by total assets will explain deviations from company profits. The greater the deviation from earnings indicates that the company is more focused on financing assets owned rather than financing for income or in other words executives at the company are also more willing to take risks because they are more dominant in financing assets. The size of executive characters who dare to take risks is measured by the standard deviation of earnings (before interest, tax, depreciation and amortization) or EBITDA divided by total assets [25]. The measurement in question is the standard deviation of this year's EBITDA / total assets and the previous year's EBITDA / total assets (consisting of two data). The formula is as follows:

$$
\text { Executive Character }=\text { Deviation Standard } \frac{\text { EBITDA }}{\text { Total Asset }}
$$

Financial ratios, namely leverage [21]. This variable is used as the control variable in this study. the higher the company's debt will be increase interest burden to be paid each period which results in smaller profits due to the increasing burden. Total liabilities divided by total assets is used as a calculation

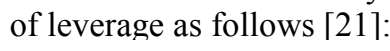

$$
\text { Leverage }=\frac{\text { Total Liabilities }}{\text { Total Asset }}
$$

\section{E. Data Processing and Analysis Techniques}

Data is processed using statistical tools in the form of Eviews 9. Data analysis was performed with descriptive statistical analysis, determination of estimation models, classical assumption tests consisting of multicollinearity and heteroscedasticity tests, panel data regression analysis consisting of coefficient of determination, statistical F test [36], [32], [33]. Hypothesis testing is done by statistical t test. The

\begin{tabular}{|c|c|}
\hline ETR & $=$ Effective tax rate \\
\hline Size & $=$ Firm size \\
\hline ROA & $=$ Return on asset \\
\hline Character & $=$ Executive character \\
\hline Lev & $=$ Leverage \\
\hline$\alpha_{0}$ & $=$ Constant value \\
\hline
\end{tabular}
panel data regression equation model that will be formed in this study is:

$$
\begin{aligned}
\text { ETR }= & \alpha_{\mathrm{o}}+\beta_{1} \text { Size }_{i t}+\beta_{2} \text { ROA } \\
& +\beta_{3} \text { Character }_{i t}+\beta_{4} \text { Lev }_{i t}+\varepsilon_{i t}
\end{aligned}
$$

Keterangan : 


$$
\begin{array}{ll}
\beta_{1}-\beta_{4} & =\text { Variable regression coefficient } \\
\varepsilon & =\text { Estimated error standard } \\
\text { it } & =\text { Amount data and years of research }
\end{array}
$$

\section{RESULTS AND DISCUSSION}

\section{Characteristics of Respondents}

Based on the stages of sampling in table 1, it was found that the number of manufacturing sector companies as the research population registered on the Stock Exchange during the 20102017 observation year were 143 companies. The final sample of the study that met the criteria was as many as 46 companies and the total financial statements presented in full according to the criteria of 8 consecutive years amounted to 368 .

TABLE I. SELECTION OF RESEARCH SAMPLES

\begin{tabular}{|c|c|c|}
\hline & Kriteria Sampel & Total \\
\hline & Registered on the Indonesia Stock Exchange in 2010-2017 & 143 \\
\hline & Companies that suffer losses before tax & $(31)$ \\
\hline & $\begin{array}{c}\text { The company does not prepare financial statements in rupiah } \\
\text { currency }\end{array}$ & $(15)$ \\
\hline & The company has an ETR more than 1 & $(1)$ \\
\hline & The company is incomplete for 8 consecutive years & $(50)$ \\
\hline \multicolumn{2}{|c|}{ Total samples (Company) } & 46 \\
\hline Total sample of the Company's financial statements (46 X 8) & 368 \\
\hline
\end{tabular}

\section{Descriptive Statistic}

The following is table 2 which shows descriptive statistical data of each variable that will be analyzed in this study.

TABLE II. DESCRIPTIVE STATISTIC

\begin{tabular}{|c|c|c|c|c|c|}
\hline & ETR & SIZE & ROA & Character & LEV \\
\hline Mean & 0,2558 & 21,638 & 0,1095 & 0,0236 & 0,4107 \\
\hline Maximum & 0,5957 & 26,412 & 0,4213 & 0,1588 & 0,8637 \\
\hline Minimum & - & 18,174 & 0,0007 & 0,0000 & 0,0943 \\
& 0,1125 & & & & \\
\hline Std. Dev. & 0,0793 & 1,6954 & 0,0862 & 0,0234 & 0,1686 \\
\hline Observations & 368 & 368 & 368 & 368 & 368 \\
\hline
\end{tabular}

Table 2 shows the value of the minimum effective tax rate (ETR) which has a negative value indicating that there are companies maximize returns or tax compensation in the relevant year. The compensation comes from the company's strategy in managing taxation so that there is a deferred tax or Final Income Tax that is not included in the calculation of increasing corporate taxable income. This results in the company obtaining fiscal adjustments and getting compensation or tax returns and not even paying taxes, so that the tax payment is negative (minus). The standard deviation value of the ETR variable is 0.0793 , which means there is a difference in the level of tax payments among sample companies of $7.9 \%$.

The average value of ROA which is estimated to be 0.1095 shows that the average sample company profit is generated through asset management of $10 \%$, while the average level of leverage is at 0.4107 which indicates that the financing of assets originating from debt is equal to $41 \%$. The standard deviation value of the ROA variable is 0.0862 and the standard deviation value of the leverage is 0.1686 . These results indicate that the difference in the level of asset management to obtain profits among the sample companies is $8.6 \%$, while the difference in the level of leverage is quite high at $16.8 \%$.

The average size of the company is closer to the maximum value of the size of the company as a whole that is equal to 21,638 which indicates that the average sample company has a larger majority size. The standard deviation value is 1.6954 which indicates that the difference in firm size between samples is quite high. The executive character has an average value of 0.0236 which is not far from the minimum value giving a statistically meaningful sample company has a relatively low risk taker character. The executive character variable has a standard deviation of 0.0234 which means that the difference in the level of risky decision making among the sample companies is $2.3 \%$.

\section{Results of Determination of Estimates and Tests for Classical Assumptions}

Determination of estimation model is done by chow test and hausman test. Both tests show that the estimation model chosen is the fixed effect model. The classic assumption test conducted shows that there are no multicollinearity problems and heteroscedasticity problems in the research model.

\section{Panel Data Regression Analysis}

The following is a table 3 of panel data regression with the estimated fixed effect model:

TABLE III. RESULT OF MODEL FIXED EFFECT DATA REGRESSION

\begin{tabular}{|c|c|c|c|}
\hline Variable & Coefficient & $\begin{array}{c}\boldsymbol{t} \text { - } \\
\text { Statistic }\end{array}$ & Prob. \\
\hline C & 1,717881 & 5,174428 & 0,0000 \\
\hline SQRT_SIZE & 0,057325 & 0,963557 & 0,3360 \\
\hline SQRT_ROA & $-0,620962$ & - & $0,0000^{* * *}$ \\
\hline SQRT_Character & $-0,244632$ & $\begin{array}{c}- \\
1,696301\end{array}$ & $0,0908^{*}$ \\
\hline SQRT_LEV & 0,084732 & 1,701632 & $0,0898^{*}$ \\
\hline R-squared & 0,432327 & & \\
\hline Adjusted R-squared & 0.344856 & & \\
\hline Prob(F-statistic) & $0,0000^{* * *}$ & & \\
\hline
\end{tabular}

*) Significant at $\alpha=10 \%$

**) Significant at $\alpha=5 \%$

***) Significant at $\alpha=1 \%$

Based on the regression results in table 3 above, the panel data regression equation model is obtained as follows:

$$
\begin{gathered}
E T R=1,7179-0,0573 \text { Size }-0,6210 R O A- \\
\text { 0,2446Character }+0,0847 \mathrm{Lev}
\end{gathered}
$$

\section{Determination Coefficient Test Results (R2)}

The adjusted R-squared value in table 3 shows that the variable firm size, ROA, executive character and leverage are able to explain the ETR variable or tax avoidance by $34 \%$ while 
the other $66 \%$ is explained by other variables not examined in this study.

\section{F Statistical Regression Test Results}

The $F$ test results can be seen in table 3 which shows a probability value of 0.0000 which is below the alpha significance level of $1 \%$. These results indicate that firm size variables, ROA, executive character and leverage simultaneously have a significant effect on ETR variables or tax avoidance. These results provide the conclusion that a feasible research model is used to test existing hypotheses.

\section{Partial Hypothesis Testing Results (Statistic t Test)}

\section{Effect of Firm Size on Tax Avoidance}

In table 3, it can be seen that the t-value of the company size is -0.963557 greater than $\mathrm{t}$ table $(-2.589441 \alpha=1 \%,-1.966521$ $\alpha=5 \%$ and $-1.649062 \alpha=10 \%)$. These results indicate that the size of the company has no negative influence on tax avoidance. The result of probability $t$ count the size of the company is 0.3360 greater than the significant level of 0.1 , which means that the first hypothesis is not supported. The conclusion from the results of testing the first hypothesis is that the size of the company does not effect tax avoidance.

Based on the consideration of long-term effects and the company's image in the eyes of the public will be bad, including in the eyes of the owner, it is likely that the company's management does not avoid the tax. Large companies will sometimes consider compliance with tax payments as a momentum to build public image and trust because they are able to contribute indirectly to the development of a company's residential area through taxes. The results of this study are in line with [28] which states that the behavior of companies in Indonesia to avoid tax is not influenced by the size of the company. The results of this study do not support the research of [22] which found that company size has a negative effect on tax avoidance. The results found by [7] related to firm size have a significant positive effect on tax avoidance and are also not supported by the results of this study. This can be indicated because the number of years of research and the number of samples used are different from previous studies.

\section{Effect of Return on Asset on Tax Avoidance}

Table 3 shows that the $t$ value of the ROA variable statistic is -6.914867 smaller than $t$ table -2.589441 at a probability level of $1 \%$. This result gives the understanding that the direction of the influence of ROA on tax avoidance is negative and in accordance with the direction of the second hypothesis. The probability value $t$ count ROA is 0.0000 smaller than 0.01 , which means the second hypothesis is supported at a significant level of $1 \%$. The conclusion from the results of testing the second hypothesis is that ROA has a significant negative effect on tax avoidance.

The company's management as an agent tends to provide high profits to gain the trust of the owner, even though the agent does not always act in the interests of the owner [16]. It is also related to the tendency of companies to present high profits when there is no bound bonus planning [14]. The tendency of the company is carried out with due regard to tax planning, so that the taxes paid are not too high. The results of this study are in line with research by [22], [1] and [29] who found that companies tend to do tax planning in the form of tax avoidance when they have high profits. [29] States the ability of invested capital is able to regulate income and tax payments. The results of this study are not in line with those found by [7], which are found to have a significant effect but have a positive direction. The results of this study are also not in accordance with [27] who find that ROA has no significant effect on tax avoidance.

\section{Effect of Executive Character on Tax Avoidance}

The results of the $t$ test for the executive character variable as shown in table 3 are $-1,696301$ smaller than 1,649062 at the $10 \%$ probability level. These results indicate that the direction of the influence of executive character on tax avoidance is negative. The probability value of $t$ executive character count is 0.0908 smaller than 0.1 , which means the third hypothesis is supported at a significant level of $10 \%$. The test results provide a conclusion that the executive character has a significant negative effect on tax avoidance.

The most dominant financing done by companies in avoiding taxes is the financing of debt because the cost of interest from the debt can be recognized by the fiscal party as a reduction in income. This financing will of course pose a risk of bankruptcy [23] if it is not matched by the ability to pay off; however executives who are risk takers tend to be brave of the risks because they feel they are able to manage these sources of financing. These results support research conducted by [6] which states those risk-taking executives will maximize the value of the company by doing certain methods and one of them is to reduce tax payments so that the profits derived by the company can be maximized.

Other studies that are in line with this study are [12] and [14] which state that only risk takers are brave to avoid tax. This study is not in line with the results of research [29] who found that executive character had a positive effect on tax avoidance. The difference in the results of the study is because the sample used came from the service sector (property, real estate, and construction building), while in this study using a sample of companies from the manufacturing sector.

Following is a table 4 summaries of the results of hypothesis testing:

\section{TABLE IV. SUMMARY OF HYPOTHESIS TEST RESULT}

\begin{tabular}{|c|c|c|}
\hline Hypothesis & Prob. & Conclusion \\
\hline $\begin{array}{c}\text { H1: Company size has a significant negative } \\
\text { effect on tax avoidance }\end{array}$ & 0,336 & $\begin{array}{c}\text { Not } \\
\text { supported }\end{array}$ \\
\hline $\begin{array}{c}\text { H2: Return On Asset has a significant negative } \\
\text { effect on tax avoidance. }\end{array}$ & $0,000^{* * *}$ & Supported \\
\hline $\begin{array}{c}\text { H3: The executive character has a significant } \\
\text { negative effect on tax avoidance }\end{array}$ & $0,091^{*}$ & Supported \\
\hline $\begin{array}{l}\text { *) Significant at } \alpha=10 \% \\
\text { **) Significant at } \alpha=5 \%\end{array}$ \\
***) Significant at $\alpha=1 \%$
\end{tabular}




\section{CONCLUSION}

Based on the results described earlier, conclusions can be drawn regarding the results of testing variables suspected of influencing tax avoidance in the manufacturing sector in 20102017 as follows: (1) The first hypothesis is the firm size has a negative effect on tax avoidance. The partial test results ( $t$ test) indicate that the size of the company does not have a statistically negative influence on tax avoidance and is also not significant so that the first hypothesis is not supported. The research sample on the average size variable of the company shows a large size, so it can be indicated that large companies tend to consider the long-term effects in order to maintain the good name and public trust of the influence caused by tax evasion. Large companies are aware that the practice of tax avoidance is not liked by the government or the public, because this practice will only slow down the administrative arrangements needed in its business business. (2) The second hypothesis is return on assets (ROA) has a negative effect on tax avoidance. The partial test results ( $t$ test) ROA variables have a direction of negative influence on tax avoidance and are significant at the level of $1 \%$ so that the second hypothesis is supported. Companies tend to increase profits to attract potential investors or build owner trust, but still pay attention to tax management so they don't pay taxes too high. Thus, even though the value of company profitability is high, companies can pay lower taxes with good management. (3) The third hypothesis is the executive character has a negative effect on tax avoidance. The partial test results ( $t$ test) executive character variables have a direction of negative influence on tax avoidance and are significant at the level of $10 \%$ so that the third hypothesis is supported. Risk-taking executives tend to be brave enough to do something challenging including tax avoidance through financing, one of which is through debt to reduce tax payments that are too high.

\section{Limitations}

This study has several limitations due to limited time and data collection. These limitations include: (1) this study still uses a few independent variables or controls so that tax avoidance in the only model is explained at $34 \%$. (2) The measurement of tax avoidance variables is only measured by the effective tax rate that includes deferred tax and current tax. (3) The executive character measurement only uses the standard deviation of EBITDA / total assets per year so that the observation only consists of two data (current year data and one year previous data). (4) This study only uses the manufacturing sector as the object of research.

\section{Implications and Suggestions}

This study found the most influential variable on tax avoidance was ROA that was significant at the level of $1 \%$ and the executive character was significant at the level of $10 \%$. Suggestions for the government, especially for the Directorate General of taxation are to pay attention to companies that have high profitability and standard deviations from high EBITDA / total assets and issue regulations that limit transactions with the purpose of tax avoidance, so that tax revenues can be maximized. Suggestions for companies are to be more aware of the importance of paying taxes because it effects the country's development.

Suggestions for further research are in order to develop the limitations of this study. The next researcher should: 1) Add other variables in the form of political connections, intensity of fixed assets and inventory intensity or other variables that are thought to influence tax avoidance so that tax avoidance can be explained (has a higher coefficient of determination) in the research model; 2) Measuring tax avoidance through a proxy for the cash effective tax rate (CETR) to see tax payments made by the company in that year; 3) Measurement of executive character should use company quarterly report data (current year and one year before), to get a standard deviation from EBITDA / total assets with a greater amount of data; 4) The sample company sector uses a sector other than manufacturing or combined with other sectors on the IDX in accordance with the sector that most contributes to tax revenues, so the results can be generalized to the population listed on the Indonesia Stock Exchange; 5) Using the size of the company (size) from small to medium size because in this study found that the size of the company with a large majority does not affect tax avoidance.

\section{REFERENCES}

[1] Agusti, W. Y. (2014). Pengaruh Profitabilitas, Leverage, Corporate Governance Terhadap Tax Avoidance (Studi Empiris Pada Perusahaan Manufaktur yang Terdaftar di BEI). Jurnal Elektronik Universitas Negeri Padang, 1-22.

[2] Allingham, M. G., \& Sandmo, A. (1972). Income Tax Evasion: A Theoretical Analysis. Journal Of Public Economics 1, 323-338.

[3] Astuti, T. P., \& Aryani, Y. A. (2016). Tren Penghindaran Pajak Perusahaan Mannufaktur Di Indonesia yang Terdaftar Di BEI Tahun 2001-2014. Jurnal Akuntansi / Volume XX, No.03, 375-392.

[4] Budiman, J., \& Setiyono. (2012). Pengaruh Karakter Eksekutif Terhadap Penghindaran Pajak (Tax Avoidance). Simposium Nasional Akuntansi XV, $1-22$.

[5] Bursa Efek Indonesia. (2019, Februari 27). Fack Book. Retrieved from PT Bursa Efek Indonesia: https://idx.co.id/ data-pasar/laporan-statistik/factbook/

[6] Carolina, V., Natalia, M., \& Debbianita. (2014). Karakteristik Eksekutif Terhadap Tax Avoidance Dengan Leverage Sebagai Variabel Intervening. Jurnal Keuangan dan Perbankan, 409-419.

[7] Darmawan, I. G., \& Sukartha, I. M. (2014). Pengaruh Penerapan Corporate Governance, Leverage, Return On Asset, dan Ukuran Perusahaan Pada Penghindaran pajak. E-Jurnal Akuntansi Universitas Udayana, 143-161.

[8] Direktorat Jenderal Pajak. (2018, Juli 24). Direktorat Jenderal Pajak Kementrian Keuangan. Retrieved from Laporan Keuangan Direktorat Jenderal Pajak: http://www.pajak.go.id/ laporan-keuangan-djp

[9] Direktorat Jenderal Pajak. (2019, Januari 20). Direktorat Jendeal Pajak Kementrian Keuangan. Retrieved from Laporan Tahunan DJP: http://www.pajak.go.id/laporan-tahunan-djp

[10] Dyreng, S. D., Hanlon, M., \& Maydew, E. L. (2008). Long-Run Corporate Tax Avoidance. The Accounting Review, 61-82.

[11] Ghozali, I. (2016). Aplikasi Analisis Multivariete Dengan Program IBM SPSS (8th ed.). Semarang: Badan Penerbit Universitas Diponegoro.

[12] Hanafi, U., \& Harto, P. (2014). Analisis Pengaruh Kompensasi Eksekutif, Kepemilikan Saham Eksekutif dan Preferensi Risiko Eksekutif Terhadap Penghindaran Pajak Perusahaan. Diponegoro Journal Of Accounting, 111.

[13] Hartono, J. (2007). Metodologi Penelitian Bisnis: Salah Kaprah dan Pengalaman-pengalaman. Yogyakarta: BPFE.

[14] Healy, P. M. (1985). The Effect of Bonus Schemes On Accounting Decision. Journal of Accounting and Economics 7, 85-107.

[15] Hutagaol, J. (2007). Perpajakan: Isu-isu Kontemporer. Yogyakarta: Graha Ilmu. 
[16] Jensen, M. C., \& Meckling, W. H. (1976). Theory of The Firm : Managerial Behavior, Agency Costs and Ownership Structure. Journal of Financial Economics 3, 305-360.

[17] Kayo, E. S. (2018, Mei 28). Saham Ok. Retrieved from Emiten, Data Arsip: https://www.sahamok.com/emiten/

[18] Kementria Keuangan. (2019, Januari 5). Kementrian Keuangan Republik Indonesia. Retrieved from Laporan Keuangan Pemerintah Pusat (LKPP): https://www. Kemenkeu.go.id/publikasi/laporan/laporan-keuanganpemerintah-pusat/

[19] Kementrian keuangan. (2019, Januari 19). Portal Data APBN Kementrian Keuangan Indonesia. Retrieved from Ringkasan APBN 2000-2017: www.data-apbn.kemenkeu.go.id/dataset/ details/1011

[20] Khadafi, M. (2017, Januari 20). "Sri Mulyani: Pajak Masih Sumber Pendapatan Utama Negara". Retrieved from timesindonesia.co.id: https://www.timesindonesia.co.id/read/140912/20170120/210711/srimulyani-pajak-masih-sumber-pendapatan-utama-negara/ ( Diakses $11 \mathrm{Mei}$ 2018)

[21] Kieso, D. E., Weygandt, J. J., \& warfield, T. D. (2011). Intermediate Accounting (Vol. 1). United States Of America: John Wiley.

[22] Kurniasih, T., \& Sari, M. M. (2013). Pengaruh Return on asset, Leverage, Corporate Governance, Ukuran perusahaan dan Kompensasi Rugi Fiskal Pada Tax Avoidance. Buletin Studi Ekonomi, 18, 58-66.

[23] Lewellen, K. (2003). Financing Decisions When Managers Are Risk Averse. Journal Of Financial Economics, 551-589.

[24] Nosic, A., \& Weber, M. (2007). Determinants of Risk Taking Behavior: The Role of Risk Attitudes, Risk Perceptions and Beliefs. Paper of University of Mannheim November 4, 1-34.

[25] Paligorova, T. (2010). Corporate Risk Taking and Ownership Structure. Bank of Canada Working Paper 2010-3, 1-44.

[26] Pohan, C. A. (2014). Manajemen Perpajakan Strategi Perencanaan Pajak dan Bisnis. Jakarta: PT Gramedia Pustaka Utama.

[27] Rosalia, Y., \& Sapari. (2017). Pengaruh Profitabilitas, Likuiditas dan Corporate Governance Terhadap Penghindaran Pajak. Jurnal Ilmu dan Riset Akuntansi, 890-909.

[28] Rusydi, M. K. (2013). Pengaruh Ukuran Perusahaan Terhadap Aggressive Tax Avoidance Di Indonesia. Jurnal Akuntansi Multiparadigma, 322-329.

[29] Saputra, M. F., Rifa, D., \& Rahmawati, N. (2015). Pengaruh Corporate Gevernance, Profitabilitas dan Karakter Eksekutif Terhadap Tax Avoidance Pada Perusahaan Yang Terdaftar Di BEI. Jurnal Akuntansi dan Auditing Indonesia, 1-12.

[30] Sawir, A. (2005). Analisis Kinerja Keuangan dan Perencanaan Keuangan. Jakarta: PT Gramedia Pustaka Utama.

[31] Soemitro, R. (1990). Dasar Dasar Hukum Pajak dan Pajak Pendapatan. Bandung: Eresco.

[32] Sugiyono. (2008). Metode Penelitian Kuantitatif Kulitatif dan $R$ dan D. Bandung: Alfabeta.

[33] Sugiyono. (2010). Metode Penelitian Pendidikan. Bandung: Alfabeta.

[34] Suliyanto. (2006). Metoda Riset Bisnis. Yogyakarta: ANDI.

[35] University Of Pennsylvania. (2019, Januari 15). Wharton Research Data Service. Retrieved from BvD OSIRIS Industrials - Financials: https://wrdsweb. wharton.upenn.edu/ wrds/ds/bvd/osiris/ind/index.cfm?navId=54

[35] Watts, R. L., \& Zimmerman, J. L. (1990). Positive Accounting Theory. USA: Prentice-Hall.

[36] Winarno, W. W. (2015). Analisis Ekonometrika dan Statistika Dengan Eviews. Yogyakarta: UPP STIM YKPN. 